\title{
The fate of embryos transferred to the oviducts of entire, unilaterally ovariectomized and bilaterally ovariectomized ewes
}

\author{
J. P. Ryan* and N. W. Moore \\ Department of Animal Husbandry, University of Sydney, Camden, New South Wales 2570, \\ Australia
}

\begin{abstract}
Summary. Embryos collected from donor ewes 2 days after oestrus were transferred to the oviducts of entire cyclic (Group EC), unilaterally ovariectomized and cyclic (Group UO), entire anoestrous (Group EA), and bilaterally ovariectomized (Group BO) ewes, and $4 \mathrm{~h}, 1,3$ or 5 days after transfer the oviducts and uteri were flushed to recover embryos. Ewes in Group BO were untreated or treated with regimens of progesterone and oestradiol designed to simulate ovarian secretion before, around the time of, and after oestrus in entire ewes.

There were no differences in the proportions of transferred embryos that were recovered, or in their location (oviduct or uterus), between the two sides of Group UO ewes and they were similar to recovery rates and locations of embryos in Group EC ewes. At 3 days after transfer, $62 \%$ and $50 \%$, respectively, of embryos recovered from ewes in Groups EC and UO were in the uterus and by 5 days the percentages had risen to $89 \%$ and $75 \%$, respectively.

With all treatment regimens fewer of the transferred embryos were recovered from Group BO ewes than from Group EC ewes and few were located in the uterus. In Group BO ewes low recovery rates, and failure of embryos to enter the uterus, appeared to be due to deficiencies in the treatment regimens rather than to effects of ovariectomy.

Most embryos recovered from treated ewes in Group BO and those in Groups EC and UO showed apparently normal development ( $86 \%$ and $79 \%$, respectively), while $65 \%$ and $75 \%$, respectively, recovered from untreated Group BO and Group EA ewes had developed normally. Only 9 of 163 embryos recovered from the untreated Group BO and EA ewes were located in the uterus and 8 of the 9 had failed to develep normally. Clearly, the steroid hormone requirements for development in the oviducis are not critical, but this is not so for the uterus.
\end{abstract}

Keywords: ewe; embryo; oviduct; transport; development

\section{Introduction}

In the ewe, the transport of ova within the ampulla of the oviduct is rapid so that by $8 \mathrm{~h}$ after ovulation ova are located at the junction of the ampulla and isthmus of the oviduct where they remain for some time before entering the isthmus $50-60 \mathrm{~h}$ after ovulation. A second period of accelerated transport follows so that by $66 \mathrm{~h}$ after ovulation most embryos are found in the uterus (Holst \& Braden, 1972; Holst, 1974).

*Present address: Human Reproduction Unit, Royal North Shore Hospital, Sydney, NSW 2065, Australia. 
The transport of embryos within the oviduct is, to at least some degree, under the control of ovarian steroid hormones secreted before and after ovulation, but in the ewe the precise roles played by oestradiol and progesterone have not been established. There are some indications that oestradiol, injected $30 \mathrm{~h}$ after ovulation, and progestagens used to control the time of oestrus and ovulation affect the transport of embryos within the oviducts (Holst \& Braden, 1972), and it has been suggested that the ovarian secretion of oestradiol 3-4 days after oestrus plays a role in the movement of embryos from the oviducts to the uterus (Cox et al., 1971; Holst \& Braden, 1972).

Moore et al. (1983) found that most embryos transferred to the oviducts of entire ewes 2 days after oestrus had reached the uterus by 3 days after transfer, whereas in ovariectomized ewes treated with a regimen of progesterone and oestradiol known to support the development of embryos transferred to their uteri 3-4 days after an induced oestrus (Miller \& Moore, 1976), only $25 \%$ of embryos recovered 3 days after transfer were located in the uterus.

The present study was designed to examine in detail the transport and development of embryos in the oviducts of entire and in steroid-treated ovariectomized ewes.

\section{Materials and Methods}

Merino ewes of 6 and 7 years of age and run under field conditions were used as donors and recipients of embryos.

Donor ewes. Superovulation was induced in donor ewes by PMSG given $40 \mathrm{~h}$ before the removal of progestagenimpregnated intravaginal sponges (Repromap, Upjohn Pty Ltd, Rydalmere, N.S.W., Australia) which had been left in situ for 12 days. Donors were mated by the direct deposition of ram semen into the uterine horns (Trounson \& Moore, 1974) and embryos were collected 2 days after insemination by flushing, under general anaesthesia, the oviducts and uterine horns with Dulbecco's phosphate buffer enriched with $10 \%$ sheep serum (DB-SS). At the time of collection embryos were of $1-4$ cells.

Recipient ewes. Recipient ewes were entire cyclic (Group EC), unilaterally ovariectomized and cyclic (Group UO), entire anoestrous (Group EA), or bilaterally ovariectomized (Group BO). Ovariectomies (Groups UO and BO) had been carried out at least 3 months before the ewes were used as recipients.

In Group EC and UO ewes oestrus was synchronized with that in their respective donors by the use of intravaginal sponges and transfers were restricted to the autumn and early winter (March to June, inclusive). Ewes in Group BO were untreated or were placed on a regimen of progesterone and oestradiol (Table 1) known to support the continued development of transferred embryos (Moore et al., 1983). Some ewes in Group BO received oestradiol (maintenance E) given during the maintenance $P$ part of the regimen (Table 1). Maintenance $E$ was given in an attempt to simulate the ovarian secretion of oestradiol in the early part of the luteal phase of the oestrous cycle in ewes in Groups EC and EA (Cox et al., 1971). Ewes given maintenance E received total doses of 28,56 or $112 \mu \mathrm{g}$ oestradiol given during Days 19, 20 and 21 of treatment, i.e. 2, 3 and 4 days after an induced oestrus. As for entire ewes, transfers were made only to treated Group BO ewes that had been detected in oestrus within $12 \mathrm{~h}$ of their respective donors. Transfers to treated and untreated ewes in Group BO were carried out throughout the year. Transfers to ewes in Group EA were restricted to the spring and early summer (October to December, inclusive), and ewes which at the time of transfer showed any evidence of functional corpora lutea were rejected.

Embryos, 2-13 in about 0.02 ml DB-SS, were transferred via the fimbria to the oviducts of each recipient by means of a smooth-ended glass pipette inserted 5-6 cm into the oviduct. Transfers were carried out under local anaesthesia (xylocaine: Astra Pharmaceuticals, North Ryde, N.S.W., Australia).

Embryos were recovered from recipients at $4 \mathrm{~h}$, or 1, 3 or 5 days after transfer. Apart from 4 ewes in Group EC and 4 in group UO, recoveries were carried out after slaughter. Ewes were killed by severing the spinal column and carotid arteries. Within $5 \mathrm{~min}$ of slaughter the oviducts were separated from the uterus by severing the uterus within $5 \mathrm{~mm}$ of the utero-tubal junction and the oviducts and uterine horns were flushed separately with 5-10 $\mathrm{ml} \mathrm{DB-SS}$. In 4 ewes in Group EC and 4 in Group UO that were not slaughtered, the recoveries were carried out at laparotomy under general anaesthesia. In these ewes the uterine horns and oviducts were flushed together by injecting 5-6 ml DB-SS into each uterine horn and flushing it through the oviduct. In these 8 ewes, therefore, it was not possible to determine whether embryos were located in the oviduct or uterus.

The number of embryos transferred to each oviduct varied between 2 and 13 with most oviducts receiving between 5 and 8. Embryos were transferred to both oviducts of ewes in Groups EC and UO but in some ewes in Groups BO and EA transfers were made to only one oviduct. This was done because of limited availability of embryos or because of damage to one oviduct.

Embryos recovered 1, 3 and 5 days after transfer were classed as having shown full, or limited, development. To be classed as having shown full development those recovered 1 day after transfer had to be of 8 , or more, cells, those recovered after 3 days to be of 16 cells or early morula, and those recovered after 5 days had to have reached the blastocyst stage of development In ewes in which only $4 \mathrm{~h}$ elapsed between transfer and recovery it was considered 
Table 1. Treatment regimens of bilaterally ovariectomized (Group BO) ewes

\begin{tabular}{|c|c|c|c|c|}
\hline $\begin{array}{l}\text { Day of } \\
\text { treatment }\end{array}$ & $\begin{array}{l}\text { Time } \\
\text { (h) }\end{array}$ & Dose & Description & $\begin{array}{l}\text { Procedure } \\
\text { or event }\end{array}$ \\
\hline 0 & 08:00 & $25 \mu \mathrm{g} \mathbf{E}_{2}$ & Base $\mathrm{E}$ & \\
\hline $3-14$ & 08:00 & $12 \mathrm{mg} \mathrm{P}$ & Priming $\mathbf{P}$ & \\
\hline 15 & $\begin{array}{l}16: 00 \\
24: 00\end{array}$ & $\begin{array}{l}3 \cdot 5 \mu \mathrm{g} \mathrm{E}_{2} \\
7 \cdot 0 \mu \mathrm{g} \mathrm{E}_{2}\end{array}$ & & \\
\hline 16 & $\begin{array}{l}08: 00 \\
16: 00 \\
24: 00\end{array}$ & $\left.\begin{array}{r}14.0 \mu \mathrm{g} \mathrm{E}_{2} \\
7 \cdot 0 \mu \mathrm{g} \mathrm{E}_{2} \\
3 \cdot 5 \mu \mathrm{g} \mathrm{E}_{2}\end{array}\right\}$ & Oestrous E & \\
\hline 17 & & - & & Oestrus \\
\hline 18 & $\begin{array}{l}06: 00 \\
18: 00\end{array}$ & $\begin{array}{l}0.50 \mathrm{mg} \mathrm{P} \\
0.625 \mathrm{mg} \mathrm{P}\end{array}$ & $\begin{array}{l}\text { Maintenance P } \\
\text { Maintenance P }\end{array}$ & \\
\hline \multirow[t]{3}{*}{19} & $06: 00$ & $0.75 \mathrm{mg} \mathrm{P}$ & Maintenance $\mathbf{P}$ ) & \\
\hline & $\begin{array}{l}12: 00 \\
18: 00\end{array}$ & $\begin{array}{l}2 \cdot 0,4 \cdot 0 \text { or } 8 \cdot 0 \mu \mathrm{E} \mathrm{E}_{2} \\
1 \cdot 00 \mathrm{mg} \mathrm{P}\end{array}$ & $\left.\begin{array}{l}\text { Maintenance E } \\
\text { Maintenance P }\end{array}\right\}$ & $\begin{array}{l}\text { Transfer of embryos and } \\
\text { recovery of embryos }\end{array}$ \\
\hline & $20: 00$ & $4 \cdot 0,8 \cdot 0$ or $16 \cdot 0 \mu \mathrm{g} \mathrm{E} \mathrm{E}_{2}$ & Maintenance E & \\
\hline \multirow[t]{4}{*}{20} & 04:00 & $8.0,16.0$ or $32.0 \mu \mathrm{g} \mathrm{E}_{2}$ & Maintenance E ? & \\
\hline & 06:00 & $1.25 \mathrm{mg} \mathrm{P}$ & Maintenance $\mathbf{P}\}$ & Recovery of embryos \\
\hline & 12:00 & $8 \cdot 0,16 \cdot 0$ or $32.0 \mu \mathrm{g} \mathrm{E}_{2}$ & Maintenance E ) & \\
\hline & $\begin{array}{l}18: 00 \\
20: 00\end{array}$ & $\begin{array}{l}1.50 \mathrm{mg} \mathrm{P} \\
4.0,8.0 \text { or } 16.0 \mu \mathrm{g} \mathrm{E}\end{array}$ & $\begin{array}{l}\text { Maintenance P } \\
\text { Maintenance E }\end{array}$ & \\
\hline \multirow[t]{3}{*}{21} & 04:00 & $2 \cdot 0,4.0$ or $8.0 \mu \mathrm{g} \mathrm{E}_{2}$ & Maintenance E & \\
\hline & 06:00 & $2 \cdot 0 \mathrm{mg} \mathrm{P}$ & Maintenance $\mathbf{P}$ & \\
\hline & $18: 00$ & $2.50 \mathrm{mg} \mathrm{P}$ & Maintenance $\mathbf{P}$ & \\
\hline \multirow[t]{2}{*}{22} & 06:00 & $3.00 \mathrm{mg} \mathrm{P}$ & Maintenance $\mathbf{P}$ & Recovery of embryos \\
\hline & $18: 00$ & $4.00 \mathrm{mg} \mathrm{P}$ & Maintenance $\mathbf{P}$ & \\
\hline \multirow[t]{2}{*}{23} & $06: 00$ & $5.00 \mathrm{mg} \mathrm{P}$ & Maintenance $\mathbf{P}$ & \\
\hline & 18:00 & $6.00 \mathrm{mg} \mathrm{P}$ & Maintenance $\mathbf{P}$ & \\
\hline 24 & $06: 00$ & $8.00 \mathrm{mg} \mathrm{P}$ & Maintenance P & Recovery of embryos \\
\hline
\end{tabular}

$\mathrm{P}=$ progesterone; $\mathrm{E}_{2}=$ oestradiol-17ß

that the time spent in vivo was too brief to allow the expression of any effects that type of ewe or treatment might have had on development.

All native unfertilized ova recovered from entire ewes, ova transferred as single cells which failed to cleave and empty zonae pellucidae that were recovered were excluded from the study.

\section{Results}

\section{Recovery and location of embryos}

In ewes in Group EC there was a major effect of time elapsing between transfer and recovery on the proportion of transferred embryos that was recovered $\left(\chi_{3}^{2}=33.325 ; P<0.001\right.$; Table 2$)$. This was due to the low rates achieved at $4 \mathrm{~h}$ (10 of 39,26\% of embryos recovered) and at 1 day (20 of $38,53 \%$ ) after transfer. Within the Group UO ewes there was no difference between the patterns of recovery from the two sides of the reproductive tract and when data for the two sides were pooled the pattern of recovery was similar to that achieved in ewes in Group EC. When recoveries were carried out at laparotomy rather than after slaughter, there was no difference between the proportions of embryos recovered from the two sides of the Group UO ewes or between ewes in Groups EC and UO. The recovery rates achieved at laparotomy in Group EC and UO ewes were not different from those achieved in the same types of ewe following slaughter $4 \mathrm{~h}$ after transfer (49 of $98(50 \%)$ vs 32 of $80(40 \%)$ at laparotomy and after slaughter respectively, $\chi_{1}^{2}=1 \cdot 776$, NS).

Overall, the recovery rate at slaughter in Group EA ewes was less than that in entire cyclic ewes $\left(66\right.$ of $165(40 \%)$ vs 78 of $\left.134(58 \%) ; \chi_{1}^{2}=9.821, P<0.005\right)$ and, as in the cyclic ewes the lowest rate of recovery was recorded when $4 \mathrm{~h}$ elapsed between transfer and recovery. Very few embryos 
Table 2. Number and site of embryos recovered after their transfer to the oviducts of ewes in Group EC (entire, cyclic), Group UO (unilaterally ovariectomized) and Group EA (entire, anoestrous)

\begin{tabular}{|c|c|c|c|c|c|c|c|}
\hline \multirow[b]{3}{*}{ Group } & \multirow{3}{*}{$\begin{array}{l}\text { Time of } \\
\text { recovery } \\
\text { after } \\
\text { transfer }\end{array}$} & \multirow{2}{*}{\multicolumn{2}{|c|}{ No. of: }} & \multicolumn{4}{|c|}{ No. of embryos: } \\
\hline & & & & \multirow[b]{2}{*}{ Transferred } & \multicolumn{3}{|c|}{ Recovered } \\
\hline & & Ewes & Oviducts & & Oviduct & Uterus & Total (\%) \\
\hline & \multicolumn{7}{|c|}{ Embryos recovered after slaughter } \\
\hline \multirow[t]{5}{*}{$\mathrm{EC}$} & $4 \mathrm{~h}$ & 4 & 8 & 39 & 9 & 1 & $10(26)$ \\
\hline & I day & 4 & 8 & 38 & 19 & 1 & $20(53)$ \\
\hline & 3 days & 3 & 6 & 25 & 8 & 13 & $21(84)$ \\
\hline & 5 days & 4 & 8 & 32 & 3 & 24 & $27(84)$ \\
\hline & Total & 15 & 30 & 134 & 39 & 39 & $78(58)$ \\
\hline \multirow{5}{*}{$\begin{array}{l}\text { UO } \\
\text { (entire side) }\end{array}$} & $4 \mathrm{~h}$ & 4 & 4 & 21 & 11 & 0 & $11(52)$ \\
\hline & 1 day & 4 & 4 & 18 & 8 & 1 & $9(50)$ \\
\hline & 3 days & 3 & 3 & 12 & 5 & 5 & $10(83)$ \\
\hline & 5 days & 3 & 3 & 14 & 2 & 11 & $13(93)$ \\
\hline & Total & 14 & 14 & 65 & 26 & 17 & $43(66)$ \\
\hline \multirow{5}{*}{$\begin{array}{l}\text { UO } \\
\text { (side of ovary removal) }\end{array}$} & $4 \mathrm{~h}$ & 4 & 4 & 20 & 11 & 0 & $11(55)$ \\
\hline & I day & 4 & 4 & 21 & 11 & 0 & $11(52)$ \\
\hline & 3 days & 3 & 3 & 12 & 5 & 5 & $10(83)$ \\
\hline & 5 days & 3 & 3 & 14 & 4 & 7 & $11(79)$ \\
\hline & Total & 14 & 14 & 67 & 31 & 21 & $43(64)$ \\
\hline \multirow[t]{6}{*}{$\mathrm{EA}$} & $4 \mathrm{~h}$ & 4 & 8 & 49 & 9 & 0 & $9(18)$ \\
\hline & I day & 4 & 8 & 45 & 22 & 2 & $24(53)$ \\
\hline & 3 days & 4 & 8 & 38 & 19 & 0 & $19(50)$ \\
\hline & 5 days & 4 & 7 & 33 & 14 & 0 & $14(42)$ \\
\hline & Total & 16 & 31 & I 65 & 64 & 2 & $66(40)$ \\
\hline & \multicolumn{7}{|c|}{ Embryos recovered at laparotomy } \\
\hline $\mathrm{EC}$ & $4 \mathrm{~h}$ & 4 & 8 & 48 & - & - & $26(54)$ \\
\hline (entire side) & $4 \mathrm{~h}$ & 4 & 4 & 25 & - & - & $11(44)$ \\
\hline \multirow[t]{2}{*}{ removal) } & $4 \mathrm{~h}$ & 4 & 4 & 25 & - & - & $12(48)$ \\
\hline & Total & 12 & 16 & 98 & - & - & $49(50)$ \\
\hline
\end{tabular}

were recovered from the uteri of anoestrous ewes, whereas in ewes in Groups EC and UO $50 \%$, or more, of embryos were located in the uterus by 3 days after transfer. There was no difference between the two sides in the location of embryos in Group UO, or between ewes in Groups EC and UO.

In Group BO given maintenance E, comparisons between ewes given the 3 doses of maintenance $\mathrm{E}$ was only possible for ewes slaughtered 3 days after transfer (Table 3 ). However, there was no effect of dose of maintenance $E$ on the proportion of embryos recovered, or on the location of the recovered embryos. Hence, data from ewes receiving the 3 doses of Maintenance $E$ were pooled for further analyses. In Group BO ewes there were effects of time of recovery $\left(\chi_{3}^{2}=32.821\right.$; $P<0.001)$ and of treatment $\left(\chi_{2}^{2}=6.846 ; P<0.05\right)$ on the proportion of embryos that was recovered, together with a significant interaction between treatment and time of recovery $\left(\chi_{6}^{2}=\right.$ 28.218; $P<0.001)$. In untreated Group BO ewes recovery rates were low at $4 \mathrm{~h}$ and at 1 day $(5$ of $47(11 \%)$ and 4 of $46(9 \%))$ and uniformly high at 3 and 5 days $(35$ of $52(67 \%)$ and 27 of 40 $(68 \%))$. In EPEP-treated ewes recovery rates declined from 21 of 43 at $4 \mathrm{~h}(49 \%)$ to 11 of $59(19 \%)$ 
Table 3. Number and site of embryos recovered from ewes in Group BO (bilaterally ovariectomized)

\begin{tabular}{|c|c|c|c|c|c|c|c|}
\hline \multirow[b]{3}{*}{ Treatment } & \multirow{3}{*}{$\begin{array}{l}\text { Time of } \\
\text { recovery } \\
\text { after } \\
\text { transfer }\end{array}$} & \multirow{2}{*}{\multicolumn{2}{|c|}{ No. of: }} & \multicolumn{4}{|c|}{ No. of embryos: } \\
\hline & & & & \multirow[b]{2}{*}{ Transferred } & \multicolumn{3}{|c|}{ Recovered } \\
\hline & & Ewes & Oviducts & & Oviduct & Uterus & Total $(\%)$ \\
\hline \multirow[t]{5}{*}{ None } & $4 \mathrm{~h}$ & 4 & 6 & 47 & 4 & 1 & $5(11)$ \\
\hline & I day & 4 & 7 & 46 & 4 & 0 & $4(9)$ \\
\hline & 3 days & 7 & 10 & 52 & 34 & 1 & $35(67)$ \\
\hline & 5 days & 4 & 8 & 40 & 21 & 6 & $27(68)$ \\
\hline & Total & 19 & 31 & 185 & 63 & 8 & $71(38)$ \\
\hline \multirow[t]{5}{*}{ EPEP } & $4 \mathrm{~h}$ & 4 & 8 & 43 & 21 & 0 & $21(49)$ \\
\hline & 1 day & 4 & 7 & 41 & 10 & 0 & $10(24)$ \\
\hline & 3 days & 6 & 9 & 58 & 15 & 2 & $17(29)$ \\
\hline & 5 days & 6 & 11 & 59 & 8 & 3 & $11(19)$ \\
\hline & Total & 20 & 35 & 201 & 54 & 5 & $59(29)$ \\
\hline \multirow[t]{7}{*}{ EPEP-E } & $4 \mathrm{~h}, 56 \mu \mathrm{g}^{*}$ & 4 & 7 & 36 & 16 & 0 & $16(44)$ \\
\hline & 1 day, $56 \mu \mathrm{g}$ & 4 & 8 & 41 & 7 & 0 & $7(17)$ \\
\hline & 3 days, $28 \mu \mathrm{g}$ & 5 & 10 & 53 & 24 & 1 & $25(47)$ \\
\hline & 3 days, $56 \mu \mathrm{g}$ & 5 & 9 & 56 & 19 & 4 & $23(41)$ \\
\hline & 3 days, $112 \mu \mathrm{g}$ & 4 & 8 & 51 & 21 & 0 & $21(41)$ \\
\hline & 5 days, $56 \mu \mathrm{g}$ & 6 & 9 & 56 & 16 & 11 & $27(48)$ \\
\hline & Total & 28 & 51 & 293 & 103 & 16 & $119(41)$ \\
\hline
\end{tabular}

${ }^{*}$ Total dose of Maintenance $E$ (see Table 1).

at 5 days. When maintenance $E$ was included in the treatment regimen recovery rates at $4 \mathrm{~h}$ and 1 day were similar to those in EPEP-treated ewes, whereas at 3 and 5 days they were greater than in EPEP-treated ewes $\left(69\right.$ of $160(43 \%)$ vs 17 of $58(29 \%) ; \chi_{1}^{2}=3.401 ; 0.05<P<0.10$ at 3 days, 27 of $56(48 \%)$ vs 11 of $59(19 \%) ; \chi_{1}^{2}=11.355 ; P<0.001$ at 5 days). Further, the highest overall recovery rate recorded in Group BO ewes was that achieved in ewes given maintenance E, but even in these ewes the recovery rate was less than that obtained in Group EC ewes (119 of $293(41 \%) v s$ 78 of $\left.134(58 \%) ; \chi_{1}^{2}=11.455 ; P<0.001\right)$.

In ewes in Group BO there was no effect of treatment on the location of embryos, and the proportion recovered from the uterus increased with increase in the interval elapsing between transfer and recovery. However, the proportion recovered from the uterus in these ewes was far less than that in Group EC ewes ( 29 of $249(12 \%)$ vs 39 of $\left.78(50 \%) ; \chi_{1}^{2}=53.0 .45 ; P<0.001\right)$.

\section{Development of recovered embryos}

In Group EC ewes there were effects of site of recovery of embryos $\left(\chi_{1}^{2}=6.364 ; P<0.02\right)$ and of time of recovery $\left(\chi_{2}^{2}=9.684 ; P<0.005\right)$ on the proportion of embryos classed as having shown full development, but there was no suggestion of a significant interaction between site and time of recovery (Table 4). In Group UO ewes there was no difference between the two sides of the reproductive tract in the proportions of embryos which showed full development. Hence data for the two sides were pooled for comparison with Group EC ewes. However, no effect of unilateral ovariectomy on development of embryos could be established. In the Group EA ewes there was a suggestion that the proportion of embryos recovered from the oviducts which showed full development was less than that in entire cyclic ewes (43 of $55(78 \%)$ vs 28 of $30(93 \%) ; \chi_{1}^{2}=3 \cdot 239$; $0.05<P<0.10)$ 
Table 4. Proportion of embryos classed as showing full development

\begin{tabular}{|c|c|c|c|c|c|c|}
\hline Group & $\begin{array}{l}\text { Time of } \\
\text { recovery } \\
\text { after } \\
\text { transfer }\end{array}$ & Oviduct & & Uterus & & $\begin{array}{l}\text { Total } \\
(\%)\end{array}$ \\
\hline \multirow[t]{2}{*}{$\mathrm{EC}$} & $\begin{array}{l}\text { I day } \\
3 \text { days } \\
5 \text { days }\end{array}$ & $\begin{array}{c}19 / 19 \\
6 / 8 \\
3 / 3\end{array}$ & & $\begin{array}{c}1 / 1 \\
13 / 13 \\
14 / 24\end{array}$ & & $\begin{array}{rr}20 / 20 & (100) \\
17 / 21 & (81) \\
17 / 27 & (63)\end{array}$ \\
\hline & Total & $28 / 30$ & $(93 \%)$ & $26 / 38$ & $(68 \%)$ & $54 / 68 \quad(79)$ \\
\hline \multirow[t]{2}{*}{$\begin{array}{l}\text { UO } \\
\text { (entire side) }\end{array}$} & $\begin{array}{l}1 \text { day } \\
3 \text { days } \\
5 \text { days }\end{array}$ & $\begin{array}{l}6 / 8 \\
5 / 5 \\
1 / 2\end{array}$ & & $\begin{array}{l}1 / 1 \\
4 / 5 \\
8 / 11\end{array}$ & & $\begin{array}{ll}7 / 9 & (78) \\
9 / 10 & (90) \\
9 / 13 & (69)\end{array}$ \\
\hline & Total & $12 / 15$ & $(80 \%)$ & $13 / 17$ & $(76 \%)$ & $25 / 32 \quad(78)$ \\
\hline \multirow[t]{2}{*}{$\begin{array}{l}\text { UO } \\
\text { (side of ovary } \\
\text { removal) }\end{array}$} & $\begin{array}{l}1 \text { day } \\
3 \text { days } \\
5 \text { days }\end{array}$ & $\begin{array}{l}9 / 11 \\
5 / 5 \\
3 / 4\end{array}$ & & $\begin{array}{l}0 / 0 \\
4 / 5 \\
4 / 7\end{array}$ & & $\begin{array}{ll}9 / 11 & (82) \\
9 / 10 & (90) \\
7 / 11 & (64)\end{array}$ \\
\hline & Total & $17 / 20$ & $(85 \%)$ & $8 / 12$ & $(67 \%)$ & $25 / 32 \quad(78)$ \\
\hline \multirow[t]{2}{*}{ EA } & $\begin{array}{l}1 \text { day } \\
3 \text { days } \\
5 \text { days }\end{array}$ & $\begin{array}{r}20 / 22 \\
16 / 19 \\
7 / 14\end{array}$ & & $\begin{array}{l}0 / 2 \\
0 / 0 \\
0 / 0\end{array}$ & & $\begin{array}{rr}20 / 24 & (83) \\
16 / 19 & (84) \\
7 / 14 & (50)\end{array}$ \\
\hline & Total & $43 / 55$ & $(78 \%)$ & $0 / 2$ & $(0 \%)$ & $43 / 57 \quad(75)$ \\
\hline \multirow[t]{2}{*}{$\begin{array}{l}\text { BO } \\
\text { (untreated) }\end{array}$} & $\begin{array}{l}1 \text { day } \\
3 \text { days } \\
5 \text { days }\end{array}$ & $\begin{array}{c}4 / 4 \\
25 / 34 \\
13 / 21\end{array}$ & & $\begin{array}{l}0 / 0 \\
0 / 1 \\
1 / 6\end{array}$ & & $\begin{array}{cc}4 / 4 & (100) \\
25 / 35 & (71) \\
14 / 27 & (52)\end{array}$ \\
\hline & Total & $42 / 59$ & $(71 \%)$ & $1 / 7$ & $(14 \%)$ & $43 / 66 \quad(65)$ \\
\hline \multirow[t]{2}{*}{$\begin{array}{l}\text { BO } \\
\text { (EPEP treated) }\end{array}$} & $\begin{array}{l}1 \text { day } \\
3 \text { days } \\
5 \text { days }\end{array}$ & $\begin{array}{c}10 / 10 \\
13 / 15 \\
5 / 8\end{array}$ & & $\begin{array}{l}0 / 0 \\
2 / 2 \\
3 / 3\end{array}$ & & $\begin{array}{rr}10 / 10 & (100) \\
15 / 17 & (88) \\
8 / 11 & (73)\end{array}$ \\
\hline & Total & $28 / 33$ & $(85 \%)$ & $5 / 5$ & $(100 \%)$ & $33 / 38 \quad(87)$ \\
\hline \multirow[t]{2}{*}{$\begin{array}{l}\text { BO } \\
\text { (EPEP-E treated) }\end{array}$} & $\begin{array}{l}1 \text { day, } 56 \mu \mathrm{g}^{*} \\
3 \text { days, } 28 \mu \mathrm{g} \\
3 \text { days, } 56 \mu \mathrm{g} \\
3 \text { days, } 112 \mu \mathrm{g} \\
5 \text { days, } 56 \mu \mathrm{g}\end{array}$ & $\begin{array}{c}6 / 7 \\
21 / 24 \\
16 / 19 \\
19 / 21 \\
11 / 16\end{array}$ & & $\begin{array}{c}0 / 0 \\
1 / 1 \\
4 / 4 \\
0 / 0 \\
10 / 11\end{array}$ & & $\begin{array}{cc}6 / 7 & (86) \\
22 / 25 & (88) \\
20 / 23 & (87) \\
19 / 21 & (90) \\
21 / 27 & (78)\end{array}$ \\
\hline & Total & $73 / 87$ & $(84 \%)$ & $15 / 16$ & $(94 \%)$ & $88 / 103 \quad(85)$ \\
\hline
\end{tabular}

*Total dose of Maintenance $\mathbf{E}$ (see Table 1).

In the Group BO ewes given maintenance $\mathrm{E}$ there was no effect of dose of maintenance $\mathrm{E}$ on development of embryos recovered 3 days after transfer $\left(\chi_{2}^{2}=0.024\right)$. Analysis of data for all Group BO ewes showed effects of treatment $\left(\chi_{2}^{2}=11.696 ; P<0.01\right)$ and of time of recovery $\left(\chi_{2}^{2}=\right.$ $11.344 ; P<0.01)$ on development. The effect of treatment was due to the low proportion of embryos recovered from untreated ewes which had developed fully $(43$ of $66(65 \%))$, whereas in EPEP and EPEP-E treated ewes 33 of $38(87 \%)$ and 88 of $103(85 \%)$, respectively, showed full development.

Data for EPEP and EPEP-E treated ewes were pooled for comparison with Group EC ewes but no difference could be found between proportions of embryos recovered from Group EC and treated Group BO ewes which were classed as showing full development (54 of $68(79 \%)$ vs 121 of $141(86 \%) ;\left(\chi_{1}^{2}=1 \cdot 381, \mathrm{NS}\right)$. 


\section{Discussion}

In no instance, irrespective of type of treatment used, was transport of embryos in the oviducts of bilaterally ovariectomized ewes similar to that in entire cyclic animals. It seems that either the steroid hormone regimens were in some way deficient or that there were physical effects of ovariectomy which could not be overcome by treatment. However, in the unilaterally ovariectomized ewes the pattern of transport on the side of ovary extirpation was not different from that in the oviduct adjacent to the remaining ovary and, furthermore, transport in the two oviducts did not differ from that in the entire cyclic animals. It therefore appears that deficiencies in treatment rather than physical effects of ovariectomy were responsible for faulty transport of embryos within the oviducts of the bilaterally ovariectomized ewes.

In the entire cyclic and unilaterally ovariectomized ewes some $50 \%$, or less, of transferred embryos were recovered at $4 \mathrm{~h}$ and at 1 day after transfer, whereas at 3 and 5 days around $80 \%$, or more, were recovered. Failure to recover embryos during the immediate post-transfer period was unlikely to be due to their rapid transport into the uterus; probably the recovery procedures used were only partly effective during this period. Slaughter, or post-mortem changes may have been responsible for the loss, but failure to improve recovery rates at $4 \mathrm{~h}$ after transfer by flushing the oviducts in vivo under general anaesthesia suggests that loss was not primarily due to the slaughter procedures, or to post-mortem changes.

In entire ewes flushing of excised sections of the oviduct showed that ova remain within the ampulla for some 2 days before moving into the isthmus (Holst \& Braden, 1972) and in this laboratory (N. W. Moore, unpublished data) it has been shown that recovery rates of ova achieved by invivo flushing of the oviducts of ewes are at their lowest during the first 1-2 days after ovulation. These low recovery rates could be due to the location of embryos close to, or even in, the fimbia during the immediate post-ovulatory period. It may be that after transfer embryos move into similar positions making their recovery difficult during the first day after transfer.

The recovery of around $40 \%$ of transferred embryos from untreated bilaterally ovariectomized and entire anoestrous ewes and the presence of some embryos in the uteri of the bilaterally ovariectomized ewes show that the retention of embryos within the oviducts and their movement from the ampulla into the isthmus and from the isthmus into the uterus are not wholly dependent upon ovarian secretions. However, the patterns of recovery of embryos from treated bilaterally ovariectomized ewes suggest that ovarian steroid hormones do play some role in the transport of -embryos. In EPEP-treated ewes recovery rates declined as the time elapsing between recovery and transfer increased and the presence of only a few embryos in the uterus could suggest continuous loss of embryos through the fimbria. The inclusion of maintenance oestradiol in the regimen increased recovery rates at 3 and 5 days but it did not improve the efficiency of transport of embryos from the oviduct to the uterus. In the entire ewe Holst \& Braden (1972) found that a single injection of $30 \mu \mathrm{g}$ oestradiol given $30 \mathrm{~h}$ after ovulation dispersed ova throughout the oviduct and it may be that the maintenance oestradiol had a similar effect resulting in some embryos moving away from the fimbria and hence decreasing their chances of loss through the fimbria. Maintenance oestradiol may have aided in the retention of embryos within the oviduct, but failure of most embryos to enter the uterus does not support the suggestion that oestradiol secreted during the early luteal phase in the ewe plays a role in the transport of embryos from the oviduct to the uterus (Holst \& Braden, 1972).

In studies on untreated ewes Holst (1974) found that the vast majority of ova and embryos had entered the uterus by 3 days after ovulation, whereas in this study 8 of $21(38 \%)$ and 3 of $27(11 \%)$ of embryos recovered from entire ewes 5 and 7 days, respectively, after oestrus were still located in the oviducts. The transfer procedures may well have influenced transport of embryos within the oviducts and delayed their entry into the uterus. Certainly, method of transfer in the rabbit can influence the survival of transferred embryos (Techakumphu et al., 1987). However, retention of embryos within the oviducts for as much as 3 days longer than normal did not have an adverse 
effect on their development, nor is it likely that their viability was impaired, as it has been shown that embryos retained in ligated oviducts of ewes for up to 8 days will develop into lambs if transferred to the uteri of recipients (Wintenberger-Torres, 1956).

In the entire anoestrous and untreated bilaterally ovariectomized ewes some $50 \%$ of embryos recovered from the oviducts 5 days after transfer showed apparently normal development and in other studies the ligated oviduct of the anoestrous ewe has been used for the in-vivo culture of embryos (Willadsen, 1982). Clearly, the steroid hormone requirements for development in the oviducts are not critical, whereas those for survival and normal development in the uterus are most critical (Miller \& Moore, 1976; Moore et al., 1983). It may be that the oviduct plays a rather passive role, its main action being one of allowing development to a stage compatible with survival and development of embryos once they reach the uterus.

This study was supported, in part, by a grant from the Australian Wool Corporation.

\section{References}

Cox, R.I., Mattner, P.E., Shutt, D.A. \& Thorburn, G.D. (1971) Ovarian secretion of oestradiol during the oestrous cycle in the ewe. J. Reprod. Fert. 24, 133-134.

Holst, P.J. (1974) The time of entry of ova into the uterus of the ewe. J. Reprod. Fert. 36, 427-428.

Holst, P.J. \& Braden, A.W.H. (1972) Ovum transport in the ewe. Aust. J. biol. Sci. 25, 167-173.

Miller, B.G. \& Moore, N.W. (1976) Effects of progesterone and oestradiol on RNA and protein metabolism in the genital tract and on survival of embryos in the ovariectomised ewe. Aust. J. biol. Sci. 29, 565-572.

Moore, N.W., Miller, B.G. \& Trappl, M.N. (1983) Transport and development of embryos transferred to the oviducts and uteri of entire and ovariectomized ewes. J. Reprod. Fert. 68, 129-135.
Techakumphu, M., Wintenbergen-Torres, S. \& Sevellec, C. (1987) Survival of rabbit embryos after synchronous or asynchronous transfer. Anim. Reprod. Sci. 12, 297-304.

Trounson, A.O. \& Moore, N.W. (1974) Fertilization in the ewe following multiple ovulation and uterine insemination. Aust. J. biol. Sci. 27, 301-304.

Willadsen, S.M. (1982) Micromanipulation of embryos of the large domestic species. In Mammalian Egg Transfer, pp. 185-210. Ed. C. E. Adams. CRC Press, Baton Roca.

Wintenberger-Torres, S. (1956) Les rapport entre l'ocuf en segmentation et le tractus maternel chez la brebis. Proc.3rd Int. Congr. Anim. Reprod.\& A.I., Cambridge, pp. 62-64.

Received 5 January 1988 